\title{
Respon Pertumbuhan dan Hasil Tanaman Sawi (Brassica junceea L.) Terhadap Pupuk Organik Cair Hasil Fermentasi Sabut Kelapa
}

\section{Response Growth and Yield of Chinese Cabbageplants (Brassica junceea L.) Against Liquid Organic Fertilizers Coconut Fiber Fermentation Results}

\author{
Novianto*, Iqbal Effendy, Aminurohman
}

\author{
Program Studi Agroteknologi, Fakultas Pertanian, Universitas Musi Rawas, Indonesia \\ *Penulis Korespondensi \\ email: noviantosp@ymail
}

\begin{abstract}
Abstrak. Sayuran sawi merupakan sayuran yang sudah terkenal di Indonesia karena mengandung nutrisi yang cukup baik sehingga bermanfaat bagi tubuh manusia dan dapat tumbuh baik pada dataran rendah maupun dataran tinggi. akan tetapi masih perlu upaya peningkatan produksi. Salah satu tindak agronomi untuk meningkatkan hasil tanaman sawi adalah dengan pemberian nutrisi berupa unsur hara seperti pupuk organik cair yang mudah dalam aplikasinya. Percobaan ini bertujuan untuk mengevaluasi efek dari masa atau waktu fermentasi sabut kelapa diperlukan dalam proses pembuatan pupuk organik cair terhadap pertumbuhan dan hasil sawi. Percobaan ini menggunakan rancangan acak kelompok non faktorial, terdiri atas 6 taraf perlakuan waktu fermentasi sabut kelapa yaitu: 0, 7, 14, 21, 28 dan 35 hari. Hasil penelitian menunjukkan bahwa, perlakuan lamanya fermentasi sabut kelapa memberikan respon sangat signifikan terhadap jumlah daun, biomas segar, berat akar dan berat tajuk tanaman, serta memacu pertumbuhan tinggi tanaman dan lebar daun. Fermentasi sabut kelapa selama 35 hari memacu peningkatan terhadap semua parameter yang diamati.
\end{abstract}

Kata kunci: fermentasi sabut kelapa, sawi, pupuk organik cair

Abstract. Chinese cabbage is a vegetable that is well-known in Indonesia because it contains enough nutrients that are beneficial to the human body. It can grow well in the lowlands and highlands. but it still needs efforts to increase production. One of the agronomic measures to increase the yield of Chinese cabbage is by providing nutrients in the form of nutrients such as liquid organic fertilizer which is easy to apply. This experiment aims to evaluate the effect of the duration of fermentation of coconut fiber needed in the process of making liquid organic fertilizer against Chinese cabbage's growth and yield. This experiment used a non-factorial randomized block design, consisting of 6 levels of coconut coir fermentation duration, namely: 0, 7, 14, 21, 28, and 35 days. The results showed that the length of treatment of coconut coir fermentation gave a very significant response to the number of leaves, fresh biomass, root weight, and weight of the plant canopy, as well as spur growth in plant height and leaf width. Coconut coir fermentation for 35 days spurred the increase in all observed parameters.

Keywords: coconut coir fermentation, chineese cabbage, liquid organic fertilizer 


\section{Pendahuluan}

Sawi merupakan dari satu dari sekian banyak tanaman hortikultura yang mempunyai harga jual dan prospek yang bagus. Pertumbuhan optimal tanaman sawi dapat tumbuh baik pada daerah bercuaca panas maupun dingin, sehingga dapat dibudidayakan pada ketinggian tempat yang tinggi dan rendah. Adapun ketinggian tempat yang dibutuhkan oleh tanaman sawi berkisar antara 100500 mdpl, sedangkan kebutuhan air dari curah hujan yang turun setiap tahunnya adalah 1000-1500 $\mathrm{mm}$. Konsentrasi ion hydrogen atau $\mathrm{pH}$ tanah yang optimum untuk tumbuh subur tanaman sawi adalah antara 6 - 7 (Yulia et al., 2011).

Pertambahan angka pertumbuhan penduduk di Indonesia dan bertambahnya wawasan tentang gizi membuat daya beli konsumen meningkat terhadap sawi . Sawi menyuplai kandungan gizi pada saat dikonsumsi cukup tinggi. Kandungan gizi dalam 100 g sawi terdapat karbohidrat 4,00 g, protein 2,30 g, lemak 0,30 g, Ca 220,00 mg, P 38,00 mg, Fe 2,90 mg, vitamin A 1,94 mg, C $102 \mathrm{mg}$ dan B 0,09 mg (Novianto et al., 2018). Pernyataan dari Direktorat Sayuran dan Tanaman Obat (2016), hasil sawi di Indonesia selama periode tiga tahun terakhir terjadinya penurunan hasil 635.728 ton pada tahun 2013 dan 600.188 ton pada tahun 2015 .

Pemupukan merupakan salah satu upaya intensifikasi untuk menambah kesuburan tanah melalui kegiatan ekstensifikasi yaitu perluasan area tanam sehingga mampu meningkatkan produksi sawi. Sementara itu menurut Effendy et al., (2019) salah satu upaya menambah hasil tanaman yaitu dengan cara memperbaik kesuburan tanah melalui pemberian pupuk organik. Pemupukan yang tepat sesuai anjuran pemerintah dengan membudidayakan tanaman secara kontemporer melalui program supra insus yang dicanangkan beberapa waktu yang lalu memiliki target untuk meningkatkan produksi tanaman dalam waktu yang singkat. Kebijakan ini menggunakan cara dan inovasi yang secara instan dalam penggunaan sarana produksi seperti penggunaan pupuk anorganik dan pestisida anorganik pada wilayah pertanian secara terusmenerus sehingga berakibat rusaknya kesuburan tanah dimasa yang akan datang dan menurunnya produktivitas tanah (Nurhasanah et al., 2012).

Pemanfaatan pupuk yang dibuat menggunakan bahan-bahan organik dapat berupa cair maupun padat. Keuntungan dalam pemanfaatan pupuk yang berbahan organik yaitu ketersediaan hara lebih cepat dan penyerapan oleh akar lebih mudah . pengaplikasian penyemprotan pupuk cair langsung dibagian organ batang dan daun. Menurut Pardosi et al., (2014). alternative bahan untuk pembuatan pupuk cair berbahan organik adalah limbah sabut kelapa. Sabut kelapa merupakan salah satu limbah buah kelapa yang selama ini jarang dimanfaatkan. Komposisi limbah sabut kelapa memiliki kandungan hara yang mampu meningkatkan pertumbuhan tanaman yaitu berupa Kalium (K) dan Fospor (P). Selain itu unsur hara yang terkandung didalam limbah sabut kelapa seperti Kalsium (Ca), Magnesium (Mg) dan Natrium (Na) (Wijaya et al., 2017). 
Agroteknika 3(1): 35-41 (2020)

Komposisi kandungan unsur hara makro dan mikro yang terdapat pada limbah sabut kelapa, yaitu: air 53,83\%, N 0,28\% ppm, P 0,1 ppm, K 6,726 ppm, Ca 140 ppm, dan Mg 170 ppm (Jamilah \& Marni, 2013). Beberapa kandungan hara yang tersedia tersebut sangat membantu dalam tumbuh dan kembangnya tanaman. Hasil penelitian Waryanti et al., (2013) menjelaskan dengan memvariasi lama waktu fermentasi diperoleh pupuk organik cair tersedia secara optimum berupa kandungan C-organik, Nitrogen, Fosfor, dan Kalium dengan tempo variasi fermentasi pada hari ke 28. Peneliti berasumsi dengan adanya pemberian perlakuan lamanya fermentasi dengan berbagai taraf pengujian ini dapat memberi informasi kualitas komposisi hara makro dan mikro yang optimal pada pupuk cair berbahan organik dari hasil variasi fermentasi sabut kelapa.

Berdasarkan beberapa hasil studi pustaka penulis tertarik untuk melakukan penelitian tentang respon pertumbuhan dan produksi tanaman sawi (Brassica junceea L.) terhadap pupuk organik cair hasil fermentasi sabut kelapa. Penelitian ini bertujuan untuk melihat pertumbuhan dan produksi tanaman sawi dengan melihat perlakuan lama fermentasi sabut kelapa sebagai POC.

\section{Bahan dan Metode}

Pelaksanaan percobaan ini dilaksanakan di Kelurahan Air Kuti Kecamatan Lubuklinggau Timur I Kota Lubuklinggau dengan ketinggian tempat 90 meter di atas permukaan laut. Uji coba perlakuan ini telah dilaksanakan pada bulan Juli 2017 sampai dengan bulan September 2017.

Rancangan Acak Kelompok (RAK) merupakan rancangan yang disusun secara non faktorial pada uji coba ini. Perlakuan yang digunakan adalah pemberian POC sabut kelapa sebanyak enam variasi perlakuan dengan diulang sebanyak empat kali. Perlakuan yang diujicobakan adalah sebagai berikut : S0 : 0 hari Fermentasi Sabut Kelapa, S1 : 7 hari Fermentasi Sabut Kelapa, S2 : 14 hari Fermentasi Sabut Kelapa, S3 : 21 hari Fermentasi Sabut Kelapa, S4 : 28 hari Fermentasi Sabut Kelapa, dan S5 : 35 hari Fermentasi Sabut Kelapa.

Pengamatan dilakukan terhadap karakter agronomis seperti pertumbuhan tinggi tanaman (cm), jumlah daun (helai), lebar daun (cm), biomas segar (g), berat akar (g), berat tajuk tanaman (g) dan indeks panen. Data yang dikumpulkan dilapangan kemudian dianalisis secara manual untuk melihat respon variasi perlakuan dengan menggunakan anova, apabila terdapat perubahan yang nyata terhadap perlakuan, dianalisis lebih lanjut dengan Uji BNJ untuk mendapatkan variasi perlakuan paling baik pada tingkat kepercayaan 5\% (Paiman, 2019).

\section{Hasil dan Pembahasan}

Berdasarkan hasil pengamatan yang dilakukan dilapangan diperoleh beberapa data peubah yang diamati, kemudian data dianalisis menggunakan analsisi keragaman. Hasil analisis keragaman pengaruh lama fermentasi sabut kelapa sebagai POC pada pertumbuhan dan hasil tanaman sawi ditampilkan pada Tabel 1. 
Tabel 1. Hasil analisis keragaman pengaruh lama fermentasi sabut kelapa sebagai POC terhadap pertumbuhan dan produksi tanaman sawi

\begin{tabular}{llrl}
\hline No & \multicolumn{1}{c}{ Parameter yang diamati } & \multicolumn{1}{c}{ Fhit S } & KK $(\%)$ \\
\hline 1. & Tinggi tanaman $(\mathrm{cm})$ & $3,90 *$ & 2,06 \\
2. & Jumlah daun (helai) & $12,04 * *$ & 2,84 \\
3. & Lebar daun $(\mathrm{cm})$ & $3,69 *$ & 4,47 \\
4. & Biomas segar $(\mathrm{g})$ & $9,73 * *$ & 3,01 \\
5. & Berat akar $(\mathrm{g})$ & $25,33 * *$ & 4,10 \\
6. & Berat tajuk $(\mathrm{g})$ & $7,93 * *$ & 3.19 \\
7. & Indeks panen & $1,46^{\text {th }}$ & 0,32 \\
\hline Keterangan: $*$ Berpengaruh nyata & $* *=$ Berpengaruh sangat nyata & \multirow{2}{*}{$\mathrm{S}=$ POC sabut kelapa }
\end{tabular}

Tabel 1 menunjukkan bahwa perlakuan lama fermentasi sabut kelapa memberi respon sangat nyata terhadap jumlah daun, biomas segar dan berat akar serta berat tajuk tanaman memberi respon nyata pada pertumbuhan tinggi tanaman dan lebar daun juga tidak memberi respon nyata terhadap indeks panen. Hal ini terjadi karena lama fermentasi sabut kelapa sebagai POC mampu menyediakan kandungan hara, N, P dan K yang akan diserap tanaman sehingga memberi respon tumbuh kembang pada tanaman sawi. Menurut Marpaung et al. (2014) ketersediaan unsur hara didalam organ tanaman dapat terpenuhi secara lengkap dengan cara pengaplikasian pupuk berbahan organik cair pada tanaman tersebut dibadingkan tanpa pemberian pupuk.

Beberapa unsur esensial seperti nitrogen, fosfor dan kalium yang tersedia pada pupuk cair berbahan organik mampu menstimulan perkembangan bunga dan buah serta meningkatkan pertambahan akar dan tunas (Leovini, 2012). Menurut Susi et al., (2018) unsur hara makro yang terdapat pada POC adalah nitrogen, phospat, kalium, kalsium, dan magnesium. Kandungan hara senyawa nitrogen bermanfaat membantu merangsang tumbuh kembang tanaman terutama pertumbuhan vegetatif seperti zat hijau daun melalui proses sintesa asam amino dan protein didalam organ tanaman. Phospat memiliki fungsi mentransfer hasil metabolisme didalam tanaman selanjutnya menstimulantpanjang akar, bakal calon biji, pembelaahan sel tanaman, memperbesar jaringan sel pembungaan dan pembuahan,. Kalium membantu dalam meningkatkan laju proses fotosintesa, mengangkut hasil asimilasi, enzim dan mineral, juga air, menambah tingkat ketahanan terhadap serangan penyakit, sedangkan kandungan hara mikro yang terdapat pada POC adalah Besi (Fe), Mangan (Mn), Tembaga (Cu) dan Seng ( $\mathrm{Zn})$. Fungsi Fe antara lain sebagai penyusun zat hijau, protein, enzim dan juga memiliki peranan perkembangan pada kloroplas, sebagai tugas mentransfer electron dalam proses metabolism, serta Mn memiliki peranan dalam proses susunan dalam ribosom dan juga menggiatkan polimerase, sintesis protein, karbohidrat, selanjutnya Mn sebagai activator ketersediaan enzim utama dalam siklus krebs, yang secara keseluruhan rangkaian tahapan dimanfaatkan dalam mensintesis klorofil.

Hasil uji BNJ dan tabulasi perlakuan lama fermentasi sabut kelapa sebagai POC pada keseluruhan parameter yang diamati dapat dilihat pada Tabel 2. 
Tabel 2. Hasil uji BNJ dan tabulasi perlakuan lama fermentasi sabut kelapa sebagai POC terhadap semua peubah yang diamati

\begin{tabular}{|c|c|c|c|c|c|c|c|c|c|}
\hline \multirow{2}{*}{ No } & \multirow{2}{*}{ Parameter pengamatan } & \multicolumn{6}{|c|}{ Perlakuan POC Sabut Kelapa (S) } & \multirow{2}{*}{$\begin{array}{r}\text { BNJ } \\
5 \%\end{array}$} & \multirow{2}{*}{$\begin{array}{c}\text { BNJ } \\
1 \%\end{array}$} \\
\hline & & S0 & S1 & S2 & S3 & S4 & S5 & & \\
\hline 1. & Tinggi tanaman $(\mathrm{cm})$ & $32,78 \mathrm{a}$ & $32,83 a$ & $33,04 a$ & $33,66 a$ & $34,20 \mathrm{~b}$ & $34,29 b$ & 1,33 & - \\
\hline 2. & Jumlah daun (helai) & $8,00 \mathrm{aA}$ & $8,19 \mathrm{aA}$ & $8,38 \mathrm{aA}$ & $8,81 \mathrm{bB}$ & $8,94 \mathrm{cC}$ & $9,00 \mathrm{cC}$ & 0,47 & 0,60 \\
\hline 3. & Lebar daun $(\mathrm{cm})$ & $12,33 \mathrm{a}$ & $12,68 \mathrm{a}$ & $12,78 \mathrm{a}$ & $13,13 \mathrm{a}$ & $13,68 b$ & $13,71 b$ & 1,13 & - \\
\hline 4. & Berat basah berangkasan (g) & $80,00 \mathrm{aA}$ & $81,88 \mathrm{aA}$ & $83,75 \mathrm{aA}$ & $87,75 \mathrm{bB}$ & $89,25 \mathrm{bB}$ & $89,38 \mathrm{bB}$ & 4,98 & 6,31 \\
\hline 5. & Berat akar $(g)$ & $3,03 \mathrm{aA}$ & $3,07 \mathrm{aA}$ & $3,26 \mathrm{aA}$ & $3,45 \mathrm{bB}$ & $3,75 \mathrm{cC}$ & $3,88 \mathrm{cC}$ & 0,27 & 0,34 \\
\hline 6. & Berat tajuk (g) & $76,97 \mathrm{aA}$ & $78,81 \mathrm{aA}$ & $80,49 \mathrm{aA}$ & $84,31 \mathrm{aA}$ & 85,51 & $85.50 \mathrm{aA}$ & 5,71 & 6.86 \\
\hline & Indeks panen & 0,960 & 0,963 & 0,960 & 0,960 & 0,958 & 0,958 & - & - \\
\hline
\end{tabular}

Keterangan : Angka-angka yang diikuti oleh huruf kecil dan huruf kapital yang sama dan pada baris yang sama berarti berbeda tidak nyata pada taraf uji $5 \%$ dan $1 \%$.

Hasil kajian pada Tabel 2 bahwa pemberian variasi lama fermentasi sabut kelapa 35 hari sebagai POC (S5) memberikan hasil terbaik pada pertumbuhan tinggi tanaman, penambahan jumlah daun, lebar daun, biomas segar dan berat akar. Hal ini menunjukkan bahwa pemberian POC sabut kelapa mampu menambah dan menyuplai kandungan hara secara lengkap yang diperlukan tanaman sawi sehingga membantu dalam proses fotosintesis tanaman dan mengakibatkan pertumbuhan dan hasil tanaman sawi menjadi baik. Menurut Jamilah and Novita (2015) bahwa ketersediaan hara yang lengkap dan berimbang mampu merangsang pergerakan proses metabolisme tanaman, sehingga memperbaiki pertumbuhan tananam sebelumnya. Pemberian perlakuan lamanya fermentasi pada POC sabut kelapa akan berpengaruh terhadap proses siklus nitrogen, proses fermentasi yang berlangsung secara tidak maksimal pada saat proses nitrifikasi apabila menggunakan semi anaerob. Menurut Suwastika et al., (2012) factor-faktor yang mempengaruhi proses nitrifikasi yaitu: oksigen, $\mathrm{pH}$, suhu, dan kelembaban. Seperti kita ketahui nitrogen merupakan unsur utama dalam penyusunan dalam sintesa protein, sementara itu sifat asal bahan dan jenis mikroba yang tumbuh mempengaruhi hasil proses peruraian protein. Selanjutnya senyawa organik terutama asam hidroksi mampu menambat dan membuat secara kompleks dan stabil dengan kation-kation $\mathrm{Ca} 2+, \mathrm{Mg} 2+, \mathrm{Fe} 3+$, dan $\mathrm{A} 13+$, dimana Phospat yang semula tertambat oleh kation-kation tersebut selanjutnya membaur dibantu oleh adanya aktivitas mikroorganisme dalam mengurai bahan organik. Sumarsih (2003). Penambahan kandungan hara pada tanaman mampu membantu memberi respon perkembangan tanaman, selain itu juga mampu meningkatkan $\mathrm{C}$ organik dimana berperan dalam meningkatkan penyerapan kation-kation dibandingkan koloid liat, disamping itu dapat mengurai fosfat $(\mathrm{P})$ terfiksasi menjadi ketersediaan P untuk kebutuhan tanaman (Sembiring et al., 2015).

Menurut Manullang et al., (2014) bahan organik cair mampu menyediakan kandungan hara adalah $\mathrm{N}, \mathrm{P}, \mathrm{K}, \mathrm{Ca}, \mathrm{Mg}$, dan $\mathrm{S}$, dimana kandungan hara tersebut diperlukan dalam jumlah yang banyak. Dari keenam unsur hara esensial tersebut yang terkandung dalam bahan organik cair tersebut mempunyai fungsi yang sangat penting dalam perkembangan tanaman. Kandungan hara $\mathrm{N}$ membantu dalam proses fotosintesis. Jika tanaman kekurangan unsur $\mathrm{N}$ maka proses fotosintesis 
Agroteknika 3(1): 35-41 (2020)

akan terhambat mengakibatkan daun menjadi hijau kekuningan apabila dibiarkan akan menguning.

Hasil uji coba Beda Nyata Jujur (BNJ) dan tabulasi, memberikan jawaban respon perlakuan tidak menggunakan POC sabut kelapa (S0) memberikan hasil terendah terhadap pertambahan tinggi tanaman, jumlah daun, lebar daun, biomas segar, berat akar dan berat bagian yang dikonsumsi atau tajuk. Praduga diperoleh bahwa tempat tumbuh kembangnya tanaman tanpa pemberian POC sabut kelapa belum adanya ketersediaan kandungan hara yang diperlukan tanaman, sehingga sulitnya akar untuk menyerap kandungan hara, karena ketidak ketersediaannya hara esensial yang dibutuhkan dalam proses fotosintesis dan berdampak pada pertumbuhan dan hasil tanaman sawi hijau. Menurut Jamilah \& Novita (2015), asupan unsur hara yang cukup pada tanaman membantu percepatan proses metabolisme yang lebih baik,selanjutnya akan berimbang pada proses tumbuh dan kembang tanaman. Menurut Zuhrah et al., (2010) menyatakan kandungan hara senyawa $\mathrm{P}$ yang berimbang akan meningkatkan sistem kerja akar lebih optimal. Bila terjadi defisit unsur hara P pada tanaman maka berakibat penurunan pada laju tumbuh dan kembangnya tanaman yang akan berimbas terhambatnya proses fotosintesis.

\section{Kesimpulan}

Hasil dari data penelitian dapat disimpulkan bahwa lama fermentasi sabut kelapa 35 hari sebagai POC menunjukan respon paling baik pada pertumbuhan sawi, dengan rata-rata hasil tanaman sawi dengan berat 89 gram.

\section{Daftar Pustaka}

Waryanti, A., Sudarno, S., \& Sutrisno, E. (2013). Studi pengaruh penambahan sabut kelapa pada pembuatan pupuk cair dari limbah air cucian ikan terhadap kualitas unsur hara makro (CNPK). Jurnal Teknik Lingkungan, 2(4), 1-7.

Direktorat Sayuran dan Tanaman Obat. (2016). Rencana dan Strategi Direktorat Sayuran dan Tanaman Obat 2016-2019. Kementerian Pertanian. Direktorat Jendral Hortikultura. Buku Direktorat Sayuran dan Tanaman Obat, hal 33.

Effendy, I., Bahri, S., \& Novianto. (2019). Dosis Pupuk Bokasi dan Pemangkasan Daun Terhadap Pertumbuhan Jagung Manis (Zea mays Saccharata Sturt). Klorofil, XIV, 1-18.

Jamilah, \& Novita, E. (2015). Pengaruh Pupuk Organik Cair Crocober Terhadap Tanaman Bawang Merah (Allium ascalonicum L.). Jurnal Ipteks Terapan Research of Applied Science and Education, 8(2), 67-73.

Jamilah, Y. N., \& Marni, Y. (2013). Peranan Gulma Chromoleana odorata dan Sabut Kelapa sebagai Bahan Baku Pupuk Organik Cair Menggantikan Pupuk Kalium untuk Pertumbuhan dan Hasil Padi Ladang. Padang: Prosiding Semnas Politani Payakumbuh Sumatera Barat, 1(1), 99-106.

Leovini, H. (2012) Pemanfaatan Pupuk Organik Cair Pada Budidaya Tanaman Tomat (Solanum lycopersicum L.). Makalah Seminar Umum. Hal: 7

Marpaung, A. E., Karo, B., \& Tarigan, R. (2014). Pemanfaatan Pupuk Organik Cair dan Teknik Penanaman Dalam Peningkatan Pertumbuhan dan Hasil Kentang. J.Hort., 24(1), 49-55. 
Manullang, G. S., Rahmi, A., \& Astuti, P. (2014). Pengaruh jenis dan konsentrasi pupuk organik cair terhadap pertumbuhan dan hasil tanaman sawi (Brassica juncea L.) varietas tosakan. Agrifor, 13(1), 33-40.

Novianto, N., Bimasri, J., \& Pratama, V. A. (2018). Respon Pemberian Pupuk Bokashi Pada Tanah Ultisol Terhadap Produksi Tanaman Sawi Hijau (Brassica Juncea L) di Dalam Polybag. Prospek Agroteknologi, 7(1), 29-37.

Nurhasanah, N., Sufardi, S., \& Syakur, S. (2012). Kesuburan Tanah pada Sistem Budidaya Konvensional dan SRI di Kabupaten Aceh Besar. Jurnal Manajemen Sumberdaya Lahan, $1(2), 151-158$.

Paiman. (2019). Perancangan Percobaan untuk Pertanian. UPY Press. Yogyakarta.

Pardosi, A.H., Irianto, \& Mukhsin. (2014). Respons Tanaman Sawi Terhadap Pupuk Organik Cair Limbah Sayuran Pada Lahan Kering Ultisol. Dalam Prosiding Seminar Nasional Lahan Suboptimal, Palembang, 26 - 27 September 2014. 77-83.

Sembiring, I.S., Wawan \& Khoiri, M.A. (2015). Sifat Kimia Tanah Dystrudepts Dan Pertumbuhan Akar Tanaman Kelapa Sawit (Elaeis guineensis Jacq.) yang Diaplikasi Mulsa Organik Mucuna bracteata. Jurnal Online Mahasiswa Fakultas Pertanian Universitas Riau, 2(2).

Sumarsih, S. (2003). Mikrobiologi Dasar. Diktat Kuliah. Jurusan Ilmu Tanah Fakultas Pertanian UPN Veteran. Yogyakarta.

Susi. N., Surtinah, \& Rizal, M. (2018). Pengujian Kandungan Unsur Hara Pupuk Organik Cair (POC) Limbah Kulit Nenas. Jurnal Ilmiah Pertanian, 14(2). 46-51.

Suwastika, A., Soniari, N. N., \& Kesumadewi, A. A. I. (2012). Biologi Tanah. Bahan Ajar. Fakultas Pertanian Universitas Udayana. Denpasar.

Wijaya, R., Damanik, M. M. B., \& Fauzi. (2017). Aplikasi Pupuk Organik Cair dari Sabut Kelapa dan Pupuk Kandang Ayam Terhadap Ketersediaan dan Serapan Kalium serta Pertumbuhan Tanaman Jagung pada Tanah Inceptisol Kwala Bekala. Jurnal Agroekoteknologi FP USU, 5(2), April 2017 (33): 249- 255.

Yulia, A. E., Murniati, \& Fatimah. (2011). Aplikasi Pupuk Organik Pada Tanaman Caisim Untuk Dua Kali Penanaman. SAGU, 10(1). 14-19.

Zuhrah, A., Aini, N., \& Wardiyati, T. (2010). Respon Morphologi Tanaman Sedap Malam (Polianthes tuberose L. cv. Roro Anteng) Terhadap Pemberian Colchicine. Buana Sains, 10(2) : 153-158. 